
Sylwia KRĘŻEL-CZOPEK, Sylwia ZIELIŃSKA, Serkan OZKAYA ${ }^{1}$

\title{
BEHAVIOUR OF CALVES
}

\section{BEHAWIOR CIELĄT}

Department of Cattle Breeding, University of Science and Technology in Bydgoszcz, Poland ${ }^{1}$ Department of Animal Science, Suleyman Demirel University, Isparta, Turkey

\begin{abstract}
Streszczenie. Aktywność życiowa cieląt zależy głównie od sposobu ich utrzymania, a nie od wieku cielęcia. Zaburzenia dobrostanu we wczesnym okresie ich życia mogą w przyszłości rzutować na opłacalność produkcji. Jednocześnie ze względu na pozytywne właściwości siary (ochrona przed chorobami) ważne jest, aby po porodzie cielę jak najszybciej się jej napiło, ponieważ układ pokarmowy nie jest jeszcze aktywny fizjologicznie. Cielę przebywające przy matce ssie średnio 7 razy na dobę (trwa to łącznie maks. 70 min). Cielę odłączone od matki karmi się zazwyczaj 2 razy dziennie. Największa potrzeba ssania u cieląt występuje w 4-5 tygodniu życia. Kilkudniowe cielęta, które przebywają w oddzielnych kojcach i są sztucznie karmione, ok. 1/5 doby spędzają na poszukiwaniu lub pobieraniu pokarmu. Narządy zmysłów bydła są bardzo dobrze rozwinięte. Zwierzęta wykorzystują zmysły zarówno do poszukiwania pokarmu, orientacji przestrzennej, jak i w kontaktach społecznych. Bydło na ogół porusza się stępem, przestraszone - kłusem, a młode cielęta chętnie galopują, przy czym wierzgają tylnymi kończynami. W czasie choroby zachowanie cieląt zdecydowanie odbiega od zachowania normalnego. Inaczej reagują one na otoczenie, zmniejsza się ich apetyt, zmienia się pragnienie, a niekiedy wygląd zewnętrzny. Niedostateczny dobrostan przejawia się w anormalnych formach zachowań, co wyraża się w trudnościach przystosowania cieląt do otoczenia (Kokocińska and Kaleta 2016).
\end{abstract}

Key words: cattle, calves, behaviour, welfare.

Słowa kluczowe: bydło, cielęta, behawior, dobrostan.

\section{INTRODUCTION}

In recent years, increased human awareness and willingness to provide farm animals with adequate housing conditions has stimulated research into the behaviour of domestic animals and how to improve their welfare (Wójcik and Olszewski 2015). In the case of domestic cattle special care must be taken with calves, because compromised welfare early in their lives may adversely affect the profitability of further production. The activity of calves, which is manifested in the different forms of behaviour, depends mainly on the way they are housed and not on their age (Reinholz 2007).

Corresponding author - Adres do korespondencji: Wojciech Neja, Department of Cattle Breeding, University of Science and Technology in Bydgoszcz, Mazowiecka 28, 85-084 Bydgoszcz, Poland, e-mail: nejaw@utp.edu.pl 


\section{PERIPARTURIENT BEHAVIOUR}

Right after calving, the cow licks the calf clean. This activity is essential in establishing the bond between the calf and the cow (Kołacz and Bodak 1999). By licking the newborn calf, the cow makes it dry and stimulates its blood circulation and fecal excretion (Pilarczyk and Hendzel 2010). Before the calf ingests colostrum, its digestive tract is not physiologically active because there is no intestinal peristalsis and the intestine is covered with mucus, which forms meconium (Stefanowska-Will 1985). Physical contact with the dam during the first day of life increases the absorption of antibodies from colostrum, which is the first and most important food for the newborn calf (Walczak 2005).

A newborn calf attempts to stand up several minutes after birth, but it usually succeeds after 30-90 minutes, when it first looks for udder. Sometimes a dairy breed calf needs a herdsperson's help when it makes no attempt to suckle for up to 6 hours (Knopski and Koberda 2004) In most cases suckling takes place within 3-4 hours of birth depending on the breed (Pilarczyk and Hendzel 2010). Because colostrum has an effect on further normal function of the calf, it should be ingested as soon as possible after birth, especially since the level of colostral immunoglobulins decreases with time and they become less able to penetrate the intestinal wall and the bloodstream (Broom 1991).

Calves adopt a characteristic posture during sucking. They splay their hind legs, and position their heads in such a way that the tongue is aligned to the esophagus. This posture ensures efficient ingestion of milk and prevents calves from sucking air. Sucking calves butt the udder with their heads to stimulate milk letdown (Kołacz and Bodak 1999). After finding the teat for the first time, the calf never forgets how to do it (Pilarczyk and Hendzel 2010).

The calf's activity, teat finding ability and colostrum ingestion are influenced by the parturition process. Calves from difficult births are less active, late to stand up, and have difficulty finding the teats and ingesting colostrum. That is why, the course of calving largely determines the calf's periparturient behaviour, health, and future development (Stefanowska-Will 1985).

Dairy breed calves remain with their dams for a much shorter period of time than do beef breed calves, which remain with their mothers for up to several months. Calves of dairy breeds are weaned immediately after birth, which produces significant behavioural changes (restlessness and nervousness) and also prevents natural ingestion of colostrum. Calves left with their mothers after birth are more active and quicker to begin suckling and running. The presence of the dam, the maternal protectiveness, and the possibility of frequent suckling have positive effects on daily weight gains, which are twice as high as in weaned calves (Kołacz and Bodak 1999). However, for veterinary and sanitary reasons (risk of being infected by the dam), some support the view that calves should be weaned early and have no contact with their mothers (Knopski and Koberda 2004).

\section{NUTRITIONAL BEHAVIOUR EATING}

Calves nurse their dams 7 times per day on average (for up to 70 minutes in total) (Bajera 1986). Weaned calves are generally fed twice per day (Shmith et al. 2014). Several-day-old calves that are housed in separate pens and artificially fed, spend around one-fifth of the day foraging or eating (Bajera 1986). 
Calves have the strongest sucking need between 4 and 5 weeks of age. This need increases from the moment of food ingestion, peaks after 5-6 minutes, and weakens. When a bucket-fed calf runs out of milk, its sucking need is the strongest and cannot be satisfied, as a result of which the calf starts to suck on pen fixtures or on other calves. Feeding from nipple buckets is a good solution. Dairy calves suckle more often than beef calves (16 vs 8 times a day). In addition, regardless of the productive type, calves prefer suckling the front teats (Pisula 2003). Calves need considerable amounts of water. Even during the milk feeding period, they should be provided with continuous access to clean water with a temperature of $20-30^{\circ} \mathrm{C}$. Cold water may cause health problems (Stefanowska-Will 1985).

Feeding plays an important role in calf management. Every animal should have access to feed and water. It is essential that the amount of milk given to calves is adequate, because excessive amounts may discourage the calves from consuming large quantities of solid feeds, which are important for the development of rumen digestive function (Soszka 2009).

\section{RUMINATION}

Rumination is an important indicator of functional changes that take place during development of the stomach (Kołacz and Bodak 1999). During the rumination process feed enters the forestomachs where it is predigested, returns to the mouth (regurgitation), and is remasticated (Litwińczuk and Szulc 2005). The forestomachs consist of the rumen, the reticulum, and the omasum (Mroczkowski and Mroczkowska 2009).

Calves start to chew the cud at around three weeks of age. Because rumination is enhanced by fibrous feeds (Grodzki 2011), they should be given to calves early on (Kołacz and Bodak 1999).

Calves kept under compromised welfare conditions (e.g. tethering, a dull, monotonous environment) are unable to satisfy their basic needs such as rumination. This gives rise to many abnormal behaviours such as head bumping against the wall, tooth grinding, tongue hanging out, empty chewing movements (Kreis-Tomczak 2006).

\section{SENSES, LEARNING, INTELLIGENCE}

Cattle have well-developed sense organs. The animals use their senses for foraging, spatial orientation, and social contacts (Pilarczyk and Hendzel 2010). Senses such as vision, hearing and olfaction are the most important elements of communication, which form the sensory channel (Curtis et al. 2017). Olfaction is an essential part of the chemical communication system, which allows for establishment of social bonds between the dam and her young (Zwolińska-Bartczak 1992; Węglarz 2003; Wójcik and Olszewski 2015).

Animal intelligence is closely associated with learning, thinking and remembering. Intelligence is influenced by both genetic and environmental factors. When confronted with a novel situation in which standard solutions fail, the animal must fall back on its own abilities, which are called intelligence (Kaleta 2005). Cattle are capable of learning quickly and remembering. Younger animals are quicker to learn than older animals, but the latter remember what they have learned for longer (Kreis-Tomczak 2006). Cattle are also known to learn more quickly in a group. This is probably because the presence of other animals makes them more confident (Litwińczuk and Szulc 2005). 
Learning involves constant adaptation to new environmental conditions and lasts throughout the animal's life. The learning process comprises the steps of association, solution finding, solution memorization, and habituation (Grodzki 2011). Animals most often learn by trial and error. This is a forced response to a novel situation, which requires different forms of behaviour from the animal (Kaleta 2005). Therefore, calves weaned from their dams are quickly able to cope with a new, unfamiliar situation. They have to quickly learn how to use a nipple or a milk feeding station. By trial and error, but also by observing more experienced animals, calves must cope with the situation that arose, for example with the need to satisfy their hunger (Grodzki 2011).

\section{CIRCADIAN RHYTHM, ACTIVITY, RESTING BEHAVIOR}

The circadian rhythm, locomotor activity and resting behaviour depend largely on the animal's age, health and physiological status (Grodzki 1999). Cattle exhibit periodicity of behaviour, which makes it important to perform activities such as watering and feeding at fixed hours, because animals adapt to a specific rhythm pattern (Kreis-Tomczak 2006).

Cattle need locomotion and adequate space for normal function and development (Pilarczyk and Hendzel 2010). They have to move to maintain physical and mental fitness. The preferred form of locomotion is related to the animal's age and sex. Young animals prefer faster gaits than older animals. In addition, males are more active than females (Pisula 2003). Cattle normally walk, and trot when frightened. Young calves often indulge in galloping, kicking with hind legs. Although cattle know how to walk backwards, they are unwilling to do so (Grodzki 2011).

Another equally important activity is resting, which comprises lying and sleep. Lying is the preferred activity among calves and those prevented from doing so may experience stress and exhaustion (Pisula 2003). The time calves spend lying down and the number of lying bouts may be used in the welfare index (Nawrocki 2009). Calves spend between 16 and 18 hours of the day in a lying position, lying down and getting up around 30-40 times. The time spent lying decreases with age.

Another important aspect of the animal's activity is play behaviour. It only occurs in a stress-free environment and not when the animal is stimulated by hunger, fear or pain (Philips and Lomas 2001). In terms of time of the day, calves are most often observed to play in the morning and evening (Mulica and Hutnik 2008). At first calves play alone, typically manifesting mock fleeing behaviour such as running, cantering (which is often combined with tail flapping), and jumping. At a later age, play takes the form of social interactions with peers. Gender differences in play behaviour have also been observed, with males spending more time playing than females and more often engaging in mock aggression and combative play (Nawrocki 2009).

To ensure high welfare levels, calves should be allowed to express species-specific patterns of behaviour, otherwise they may exhibit unwanted behaviours (Baxter 1983).

\section{SOCIAL BEHAVIOR}

Cattle, being herd animals, display a wide range of social behaviours (Grodzki 2011). Social or herd behaviour can be divided into two basic groups: friendly and aggressive (Mulica and Hutnik 2008). 
For a calf, contact with the dam and other calves of similar age is essential (Pisula 2003). The need for social interactions increases when calves reach 3-4 weeks of age (Kołacz and Bodak 1999). Calves kept in isolation during the first few months of age find it difficult to communicate with other calves later in life (Pilarczyk and Hendzel 2010). What is more, calves kept in groups without contact with their dams suck each others' ears, which may cause serious infections (Knopski and Koberda 2004). The communication system in a group is clear for all members. It is genetically determined (Grodzki 2011).

Another important behaviour is the desire for comfort and efforts to improve well-being, particularly by mutual grooming and self-grooming (Knopski and Koberda 2004). The aim of grooming is to remove droppings and urine in order to keep the skin and hair clean (KreisTomczak 2006). For animals it is important to perform grooming on other animals, which is known as allogrooming (Pisula 2003). Allogrooming often begins with sucking the neck or head, followed by other parts of the body (Pilarczyk and Hendzel 2010). Calves lacking the opportunity for mutual licking tend to engage in (often excessive) licking of their own hair coat. This creates the risk of hair balls being formed in the rumen, which may give health problems (Knopski and Koberda 2004).

The comfort behaviours in animals include behavioural categories that serve to maintain good health, normal condition and well-being (Kaleta 2005).

Social hierarchy is formed in groups as small as two animals. It prevents aggression between individuals (Grodzki 2011). Factors that determine individual rank and position in the social hierarchy are combativeness, and, to a lesser extent, perseverance. Permanent groups live in stable social hierarchies, enabling the individuals to coexist peacefully (Pilarczyk and Hendzel 2010). Social hierarchy is reestablished every time a new animal is introduced. This may involve pushing and even fighting (Grodzki 2011). To prevent these behaviours and unnecessary stressful situations for animals, changes in herd composition should be avoided as far as possible (Pilarczyk and Hendzel 2010).

\section{BEHAVIOUR OF SICK CALVES}

Sick animals visibly change their behaviour in the initial stage of the disease. They respond differently to the environment, with depressed appetite, variable thirst, sometimes changes in external appearance (Strzetelski 2012). All types of diseases are most noticeable in calves. Diseased calves eat less, more slowly and shortly. Feed consumption decreases by as much as $60 \%$ when diarrhea and digestive disorders coincide. Diseases of calves may cause abnormal growth and negatively affect their development and thus productivity, at the same time diarrhea in newborn calves is a major cause of morbidity and mortality Such animals are less suitable for breeding (Pilarczyk and Hendzel 2010).

\section{UNWANTED AND STEREOTYPED BEHAVIOURS}

Animals manifest inadequate welfare levels through abnormal forms of behaviour, which shows that calves find it difficult to adapt to the environment (Grodzki 2011). Unwanted behaviours include normal behaviours occurring with abnormal frequency as well as completely 
new forms of behaviour, which are nonexistent under natural conditions (Pilarczyk and Hendzel 2010). Calves often display behaviours such as sucking other calves and sucking on pen fixtures. This is caused by unsatisfied sucking reflex (Grodzki 2011).

Excessive mutual licking often occurs in calves due to a lack of social contacts or occupation. "Drinking" the urine from the penis is also sometimes observed. This behaviour is most often found in bull calves kept in pen groups, and happens when calves are fed diets low in fibre. This behaviour may occur in calves as a substitute for sucking (Pilarczyk and Hendzel 2010).

Another behaviour observed in calves is leaning. Animals lean the forehead or the muzzle on another animal or against the fixtures. This behaviour probably expresses frustration or pain (Pilarczyk and Hendzel 2010).

Behavioural pathologies in calves also include stereotyped behaviours. Stereotypies are deviations from normal behavioural patterns of a species. They are movements that are repetitive and without purpose (Broom 1991). In animals, stereotypies are not only different from the norm, they may also be destructive for them. Stereotypic behaviour is the reaction of animals that have difficulty in coping with the environment. The frequency of such behaviours increases with age (Reinholz 2007). In cattle, stereotyped behaviours are most often found under intensive management, where they take the form of oral behaviours such as bar biting, tongue playing, and tongue rolling (Pisula 2003). Sometimes the calves adopt abnormal postures such as dog-sit postures (sitting with forelegs stretched out). This posture mostly results from inadequate space and the calf is unable to normally stand up or lie down (Pilarczyk and Hendzel 2010).

It is very important for calves to be able to stay with their mothers. The moment the calf is separated from the dam is decided by the breeder. Calves reared with their mothers were found to vocalize an average of 17 times during the first day of life, whereas those removed from their mothers vocalized 392 times on average, often because of defecation problems (Broom 1991). Calves that remained with their dams had better weight gains, were less frequently affected by diseases, and were quite active in socializing with herdmates. On the other hand, early weaned calves are less resourceful and usually do not dominate other individuals in the herd (Reinholz 2007). Therefore, it is best to leave the calves with their dams to ensure high welfare levels (Litwińczuk and Szulc 2005).

\section{HOUSING SYSTEMS}

The housing systems for calves include individual pens, hutches, and group pens. Whatever the system, calves should be provided with ample room for lying with the forelegs stretched and the head lying on the bedding, or lying on the side. Calves spend around $15-20 \%$ of their time lying in one of the above postures (Pilarczyk and Hendzel 2010).

During the first days of life, calves should be provided with adequate rest and individual treatment. Calves should be kept individually in pens covered with ample bedding (Kołacz and Bodak 1999). Keeping calves in individual pens reduces the risk and spread of diseases to which they are highly susceptible early in life. Individual penning also prevents the calves from cross-sucking (Kokocińska and Kaleta 2016). 
According to standards, calves weaned from their mothers can be housed individually or in groups. However, after 8 weeks of age calves must be kept in group pens (Pilarczyk and Hendzel 2010), which include those covered with bedding, deep-litter pens, pens with a feeding passage, and self-cleaning pens (Litwińczuk and Szulc 2005). According to standards, in farms which keep 6 calves or more at the same time, calves older than 8 weeks must be maintained in groups. The animals should be matched by age to avoid stress resulting from older animals dominating younger and weaker animals. The calves must be provided with freedom of movement and continuous access to feed and water (Philips and Lomas 2001), as well as dry and clean resting area (Pilarczyk and Hendzel 2010).

\section{CONCLUSION}

Keeping of calves in hutches has many advocates. This system is justified by better health of the calves, because normal calf houses are the breeding ground for many diseases. They are often characterized by excessive moisture, high temperature, and high concentration of harmful gases and pathogens while having inadequate ventilation and lighting . Calves should be properly prepared before being moved into hutches. They should be given colostrum and dried. Once the calf is well dried, it can function well in a hutch even at low temperatures, provided that the hutch is protected from wind.

\section{REFERENCES}

Bajera W. 1986. Fizjologiczne podstawy użytkowania bydła. Warszawa, PWRiL 374-380. [in Polish] Baxter M.R. 1983. Ethology in environmental design for animal production. Appl. Anim. Eth. 9, 207-220.

Broom D.M. 1991. Animal welfare concepts and measurement. J. Anim. Sci. 69, 4167-4175.

Curtis G.C., Argo C. McG., Jones D., Grove-White D.H. 2017. Impact of feeding and housing systems on disease incidence in dairy calves. Vet. Rec. 1-5.

Grodzki H. 1999. Żywienie i wychów cieląt i jałówek hodowlanych. Warszawa, Oficyna Wydaw. „HOŻA”. [in Polish]

Grodzki H. 2011. Metody chowu i hodowli bydła. Warszawa, Wydaw. SGGW, 62-63. [in Polish]

Kaleta T. 2005. Zmiany behawioralne u zwierząt domowych i interakcja człowiek - zwierzę we współczesnym chowie [Behavioural changes in domestic animals and the human animal interaction in modern farming]. Rocz. Nauk PTZ 1, 24-75. [in Polish]

Knopski L., Koberda M. 2004. Feromony człowieka. Warszawa, Wydaw. Nauk. Scholar, 6-29. [in Polish]

Kokocińska A., Kaleta T. 2016. Znaczenie etologii w naukach o dobrostanie zwierząt [The role of ethology in animal welfare]. Rocz. Nauk. PTZ 12(1), 49-62. [in Polish]

Kołacz R., Bodak E. 1999. Welfare of animals and criteria of its evaluation. Med. Weter. 55(3), 147-153.

Kreis-Tomczak K. 2006. Cielętniki [Calf houses]. Bydło 10, 40-43. [in Polish]

Litwińczuk Z., Szulc T. 2005. Hodowla i użytkowanie bydła. Warszawa, PWRiL, 361-373. [in Polish]

Mroczkowski S., Mroczkowska A. 2009. Cierpienie zwierząt gospodarskich [Suffering in farm animals]. Prz. Hod. 9, 31. [in Polish]

Mulica E., Hutnik E. 2008. Utrzymywanie cieląt i jałówek w kojcach grupowych na ściółce [Housing calves and heifers in group pens on litter]. Bydło 5, 48-50. [in Polish]

Nawrocki L. 2009. Technika a dobrostan bydła. Opole, Wydaw. POpol. [in Polish]

Phillips C., Lomas C.A. 2001. The perception of color by cattle and its influence on behavior. J. Dairy Sci. 84, 807-813. 
Pilarczyk B., Hendzel D. 2010. Higiena wychowu cieląt [Hygiene of raising calves]. Bydło 11, 48-49. [in Polish]

Pisula W. 2003. Psychologia zachowań eksploracyjnych zwierząt. Gdańsk, Gd. Wyd. Psych., 25-30. [in Polish]

Reinholz A. 2007. Znaczenie wiedzy o zachowaniu zwierząt w kontekście dobrostanu na przykładzie bydła domowego Bos taurus taurus. Warszawa, Wydz. Psych. UWarsz., 132-145. [in Polish]

Schmidt S.E., Neuendorff D.A., Riley D.G., Vann R.C., Willard S.T., Welsh T.H. Jr., Randel R.D. 2014. Genetic parameters of three methods of temperament evaluation of Brahman calves. J. Anim. Sci. 92, 3082-3087.

Soszka M. 2009. Zimny odchów cieląt [Cold rearing of calves]. Bydło 8/9, 98-100. [in Polish]

Stefanowska-Will J. 1985. Wpływ przebywania z matką na zachowanie wzrost i stan zdrowia cieląt [Effect of staying with the dam on behaviour, growth and health of the calves]. Zesz. Probl. Postęp. Nauk. Rol. 300, 317-324. [in Polish]

Strzetelski J. 2012. Rozwój przewodu pokarmowego, a żywienie cieląt. Kraków-Balice, Inst. Zootech. PIB. [in Polish]

Walczak J. 2005. Dobrostan bydła a warunki jego utrzymania. Kraków, Wydaw. Inst. Zoot. 93. [in Polish]

Węglarz A. 2003. Hodowla bydła. Kraków, Wydaw. AR. [in Polish]

Wójcik P., Olszewski A. 2015. Wykorzystanie pedometrów do analizy aktywności dobowej i płodności krów rasy limousine [Use of pedometers to analyse 24-hour activity and fertility of limousin cows]. Folia Pomer. Univ. Technol. Stetin., Agric., Aliment., Pisc., Zootech. 322(36)4, 119-124. [in Polish]

Zwolińska-Bartczak I. 1992. Genetyczne uwarunkowania zwierząt gospodarskich [Genetic determinants of farm animals]. Pr. Mater. Zootech. 1(zesz. spec.), 49-60. [in Polish]

\begin{abstract}
The activity of calves depends mainly on the way they are housed and not on their age. Because compromised welfare early in life may affect the profitability of future production, calves need to be fed colostrum after birth because their digestive tract is not physiologically active. Calves nurse their dams 7 times per day on average (for up to 70 minutes in total). Weaned calves are generally fed twice per day. Calves have the strongest sucking need between 4 and 5 weeks of age. Several-day-old calves that are housed in separate pens and artificially fed, spend around one-fifth of the day foraging or eating. Cattle have well-developed sense organs. The animals use their senses for foraging, spatial orientation, and social contacts. Cattle normally walk, and trot when frightened. Young calves often indulge in galloping, kicking with hind legs. During disease, the behaviour of calves considerably differs from normal. They respond differently to the environment, their appetite decreases, with changes in thirst, and sometimes in external appearance. Inadequate welfare levels lead to abnormal forms of behaviour, which are reflected in problems adapting to the environment (Kokocińska and Kaleta 2016).
\end{abstract}

